\title{
Factors Affecting the Competitive Capacity of Commercial Banks: A Critical Analysis in an Emerging Economy
}

\author{
Le Kieu Oanh Dao ${ }^{1}$, Thuy Tu Pham ${ }^{2} \&$ Van Chien Nguyen ${ }^{3}$ \\ ${ }^{1}$ Banking University of Ho Chi Minh City, Vietnam \\ ${ }^{2}$ University of Finance - Marketing, Ho Chi Minh City, Vietnam \\ ${ }^{3}$ Thu Dau Mot University, Vietnam \\ Correspondence: Van Chien Nguyen, Thu Dau Mot University, Vietnam. E-mail: chiennv@tdmu.edu.vn or \\ chienmpp3@gmail.com
}

Received: March 23, 2020

Accepted: April 28, 2020

Online Published: July 7, 2020

doi:10.5430/ijfr.v11n4p241

URL: https://doi.org/10.5430/ijfr.v11n4p241

\begin{abstract}
This research was conducted to investigate the factors influencing the commercial bank's competitive capacity in an emerging country. Data were collected from the domestic-owned commercial banks and foreign-owned commercial banks listed on Vietnam's Stock Exchange over the period of nine years from 2010 to 2018. Three statistic approaches were employed to address econometrics issues and to improve the accuracy of the regression coefficients: Pooled Ordinary Least Square (Pooled OLS), Random Effects Model (REM), and Fixed Effects Model (FEM). To correct the diagnostics and endogeneity in the model, the study uses Generalized Least Square (GLS) and Generalized Method of Moments (GMM). In order to account for the degree of competitive capacity we use Lerner index. Results demonstrate that the impact of bank-specific characteristics on market power in banks is statistically significant, and there are substantial distinguishments of economic consideration among these factors. In addition, a bank with a higher level of competitive capacity in the previous year will outstandingly generate competitive capacity in the current year. Another possibility, a greater level foreign investment into the banks in the host country could further encourage competitive capacity in the banking system. Finally, economic growth rate has no impact on competitive capacity at a significant level of 5\% while a positive effect from inflation on bank's market power could be found.
\end{abstract}

Keywords: bank, competitive capacity, GMM, Lerner, marginal cost

JEL Classification Codes: B26, G21, G31, G32, M41

\section{Introduction}

Banking sector in emerging economies has seen important transformations in the development of financial market. The bank sector performance and especially competitive capacity of financial institutions has recently reappeared in the economic and financial literature (Chen et al., 2018; Van, 2019; Mukherjee, 2020; Zouaoui \& Zoghlami, 2020).

While there are several empirical studies that have investigated the factors of the competitive capacity of commercial banks, most of the literature has focused on advanced and emerging economies (Soedarmono et al., 2011; Delis, 2012; Kasman \& Carvallo, 2014; Fu et al., 2014; Chen et al., 2018; Zouaoui \& Zoghlami, 2020). As theoretical models pointed out that banking performance has played a key role in leading the economic growth (Tan \& Floros, 2013). Yet, a healthy bank is promoted to support more lending and reduce transaction fees. If the bank has high costs of transactions such as banking fees, customer service, and overhead, it will challenge the profitability of business (Mukherjee, 2020; Nguyen, 2020).

The commonly accepted view that the competitive capacity has been affected by a variety of bank-specific, competitive environment factors, and macroeconomic factors. As suggested in Berger et al. (2008), Elsas et al (2010), Sanya \& Wolfe (2011), Manlagnit (2011), Fu et al. (2014), Schaeck \& Cihák (2014), Fernandez \& Garza- Garcia (2015), Mustafa \& Toci (2017), and Yuanita (2019), bank-specific factors can negatively or positively affect market power of a bank. Followed that, a bank with more market power can achieve higher records of overall stability. Regarding the competitive environment factors, the results indicate that a bank with higher level of foreign investment has higher market power (Claessens, 2001; Manlagnit, 2011). This conclusion is explained by the fact 
that market power in the banking system in the host country can be increased by the every present of foreign investment that can also foster financial market and competition (Hussain and Hassan, 2020; Hussain et al., 2020). On the asset side, the impact of macroeconomic factors on the capacity of competition in the financial market can be also found (Delis, 2012).

In the case of Vietnam, although the banking sector has been very important in the development of financial system and support to the economic growth at roughly 7 per cent since economic reforms in 1986 (Tran \& Van, 2013; Nguyen, 2020), but the banking system's profit significantly decreased because of non-performing loan (NPL) in the financial sector and economic depression in the period of $2012-2015$. NPL in 2012 recorded a peak of $17.2 \%$ total loans, but decreased to $4.84 \%$ in 2019. The whole banking sector showed an upward trend during the period $2012-$ 2018. In recent years, the Vietnamese banking system has changed significantly. A recent survey from the State bank of Vietnam (SBV) denoted that credit growth was maintained at 8-9 per cent and capital mobilization rose by 9-10 per cent. Further, a large number of foreign banks have been allowed to participate in the banking sector, approximately 61 banks with $100 \%$ foreign capital and branches, representative offices of foreign banks in Vietnam, 2 joint venture banks and many joint stock banks owned by foreign investment.

This situation raised a new set of concerns for policymakers and researchers to study the banking sector. To the best of our knowledge, there has been no empirical study on the factors that influence the market power of commercial banks in an emerging economy. Therefore, this study aims to examine three important factors affecting Vietnamese banking market power, namely the bank-specific, competitive environment and macroeconomic factors. The first group of bank-specific factors that are related to the market power in the previous year, bank size, bank equity, the loans to assets ratio, the market share of mobilized capital, loan loss provisions, income diversification, growth of total assets, and form of ownership. The second group of competitive environment factors is in agreement with the rate of foreign-owned bank branches on the banking sector, and the rate of foreign-owned banks' assets on the banking sector's assets. The third group of macroeconomic factors is related to GDP growth and inflation which the banking system is in operation.

The remainder of the paper is organized as follows. In Section 2, the study discusses the factors affecting the competitive capacity and their relation to key economic variables. In Section 3 we present research methodology, descriptions of research variables, selection of research samples and data collection. In Section 4, we show our main results. Section 5 discusses the results while conclusion is in Sector 6.

\section{Literature Review}

Referring to the study of factors affecting competitive capacity of commercial banks, there have many types of researches in terms of both theoretical and empirical. Theoretically, numerous studies have given many theoretical frameworks related to competitive capacity of banks such as theory of Berger et al. (2008), Elsas et al. (2010), Sanya \& Wolfe (2011), Manlagnit (2011), Fu et al. (2014), Schaeck \& Cihák (2014), Fernandez \& Garza- Garcia (2015), Mustafa \& Toci (2017), Yuanita (2019), and Kamran et al. (2020). These studies aim to discuss the factors that can impact the market power of a bank in the specific countries. Lerner index measures a bank level of market power by relating price to marginal cost in that bank. In addition, Lerner index can also use price elasticity of demand in order to measure market power. Casu \& Girardone (2009) discuss that Lerner index of monopoly power is an indicator indicating for the degree of market power and therefore this index can be measure of competition in the banking system. Further, Berger et al. (2008) debates that Lerner index has a range from a low of 0 to a high of 1 . A higher value of this index is correlated with a greater market power. Therefore, it is necessary to to think that the only measure of competition is Lerner index that is certainly computed at the bank level.

In terms of empirical research, many studies have concluded that bank-specific factors can influence the market power in a bank. As shown by Carbó et al. (2009) in the banking sector in 14 European nations, assessing the competitive capacity in the banking markets, in particular in existing indicators denoting for competitive capacity can be found to provide numerous conflicting predictions in the whole world, over time, and within countries. Carbó et al. (2009) point out that indicators of competition can frequently compute different things, and are affected by cross-country distinction in cost efficiency, income levels of fee, and real GDP, inflation. The main results indicate that banking sector competition can be somewhat stronger than discussed by traditional measures. Claessens et al. (2001) conduct on a study by using 7900 observations in the bank sector from 80 nations during the period of 19881995, foreign-owned banks can make higher profits than domestic-owned banks in emerging countries, but the opposite result can be found in developed countries. In fact, foreign-owned banks have created more competitive pressure for domestic banks (Manlagnit, 2011). 
As observed in the recent study, Nagore \& Villarroya (2005) conclude that bank-specific factors are the most important for discussing the distinction in the competitive capacity among banks. The results indicate that although the effect of the total of bank-specific factors on market power in banks is statistically significant, but there exists some differences of economic consideration among these factors, especially high magnitude of the effect of bank size and, and efficiency. More specifically, a $10 \%$ increase in bank size or efficiency, it could certainly generate a $3.5 \%$ and $11.1 \%$ of market power, respectively. Further, a higher level of bank market concentration could positively impact market power, competitive capacity being increasingly lower in countries with less every foreign presence inside the bank's shareholders as well as with lower contribution of state-owned banks.

Further investigated, Nagore \& Villarroya (2005) also show that banks will own a higher level of market power in countries with underdeveloped banking sector. By contrast, market power will be lower in countries with highly developed stock markets. In the analysis on bank regulations, banks in the country with a lower level of freedom, and in the country with the regulation restrictions on the business, competitive capacity is significantly greater.

Soedarmono et al. (2011) using a sample in Asian countries' commercial banks in the years of 2001-2007, highlighting that a greater market power in banking could reduce the stability in the financial market. Despite of bank's greater capitalization in less competitive markets, the default risk still remains higher. In addition, a country with a higher economic growth can contribute to neutralize a greater risk taking and a higher level of instability in less competitive markets. Chen et al. (2018) suggest that the existence of information asymmetry among banks, investors, and capitalists will have an impact on investors' choice, as a result of that affecting the competition. The study deeply analyzes that a number of the bank branches are involving to the market competition among banks, and in contrast a larger size of bank can greater exploit private information.

Following the approach in Zouaoui \& Zoghlami (2020), who investigate the linkage between revenue diversification and market power by using a sample in Middle Eastern and North African (MENA) countries' banks over the period of 1993-2014. By employing a generalized method of moments (GMM), the results point out that the level of bank market power will decrease in relation to positive revenue diversification fluctuations. In contrast, a bank with a higher level of market power could get more engaged in the non-traditional activities.

\section{Data and Methodology}

\subsection{Data}

The sample used in this study includes yearly data from 2010 to 2018. This study has collected the secondary data in Ho Chi Minh City Stock Exchange (HOSE) and Hanoi Stock Exchange (HNX). The data includes both domestic-owned commercial banks and foreign-owned commercial banks. Approximately 31 domestic-owned commercial banks and 11 foreign-owned commercial banks used in this study has mainly represented for $99.78 \%$ total Vietnamese bank's assets.

The study employed macroeconomic factors such as GDP growth and inflation of Vietnam during the period of 2010 - 2018. These indicators are retrieved from World Bank and General Statistics Office of Ministry of Planning and Investment.

\subsection{Methodology}

In this study, panel data analysis is used in order to study the factors influencing competitive capacity of commercial banks. To do this we have disaggregated the three major factors: the first for bank-specific factors, the second for competitive environment factors, and the third for macroeconomic factors. The empirical previous studies have been explained that the competitive capacity could be denoted by Lerner Index (Berger et al, 2008; Fu et al, 2014). Theoretically, if the Lerner Index has been increasingly low, a bank is less likely to be able to charge over its marginal cost, hence it is weaker its monopoly power in the market and more competitive. In equation (1), Lerner Index can be measured by:

$$
\text { Lernerit }=\left(\mathrm{P}_{\mathrm{it}}-\mathrm{MC}_{\mathrm{it}}\right) / \mathrm{P}_{\mathrm{it}}=-1 / \mathrm{E}_{\mathrm{d}}
$$

Where:

$\mathrm{P}_{\mathrm{it}}$ is the market price set by the bank, reflecting for the quotient of total revenues on total assets of the bank $\mathrm{i}$ at the time t;

$\mathrm{MC}_{\mathrm{it}}$ is the bank's marginal cost $\mathrm{i}$ at the time $\mathrm{t}$;

Ed is the price elasticity of demand; 
The Lerner index has a range from a low of 0 to a high of 1 . A higher value of this index is consistent with a greater market power. In specific, when $\mathrm{P}=\mathrm{MC}, \mathrm{L}=0$; such a firm has no market power. When $M C=0$, Lerner's index is equal to unity, indicating the presence of monopoly power.

In respect to MC, we follow the study of (Kasman \& Carvallo, 2014). This indication is calculated by two steps as follows:

Firstly, we do the logarithm of the equation

$$
\begin{aligned}
& \text { LnTCit }=\alpha_{0}+\alpha_{1} \operatorname{LnQ}_{\mathrm{it}}+(1 / 2) \alpha_{2}\left(\mathrm{LnQ}_{\mathrm{it}}\right)^{2}+\alpha_{3} \mathrm{LnW} 1_{\mathrm{it}}+\alpha_{4} \mathrm{LnW} 2_{\mathrm{it}}+\alpha_{5} \mathrm{LnW} 3_{\mathrm{it}}+\alpha_{6} \mathrm{LnQ}_{\mathrm{it}} \mathrm{LnW} 1_{\mathrm{it}}+\alpha_{7} \mathrm{LnQ}_{\mathrm{it}} \mathrm{LnW} 2_{\mathrm{it}} \\
& +\alpha_{8} \mathrm{LnQ}_{\mathrm{it}} \mathrm{LnW} 3_{\mathrm{it}}+\alpha_{9} \mathrm{LnW} 1_{\mathrm{it}} \mathrm{LnW} 2_{\mathrm{it}}+\alpha_{10} \mathrm{LnW} 1_{\mathrm{it}} \mathrm{LnW} 3_{\mathrm{it}}+\alpha_{11} \mathrm{LnW} 2_{\mathrm{it}} \operatorname{LnW} 3_{\mathrm{it}}+(1 / 2) \alpha_{12}\left(\operatorname{LnW} 1_{\mathrm{it}}\right)^{2} \\
& +(1 / 2) \alpha_{13}\left(\operatorname{LnW} 2_{\mathrm{it}}\right)^{2}+(1 / 2) \alpha_{14}\left(\operatorname{LnW} 3_{\mathrm{it}}\right)^{2}+\alpha_{15} \mathrm{~T}+(1 / 2) \alpha_{16} \mathrm{~T}^{2}+(1 / 2) \alpha_{17} \mathrm{TLnQ}_{\mathrm{it}}+\alpha_{18} \mathrm{TLnW} 1_{\mathrm{it}} \\
& +\alpha_{19} \mathrm{TLnW}_{\mathrm{it}}+\alpha_{20} \mathrm{TLnW}_{\mathrm{it}}+\varepsilon_{\mathrm{it}}
\end{aligned}
$$

We have:

$$
\mathrm{MC}=\frac{\mathrm{dTC}}{\mathrm{dQ}}=\left(\frac{\alpha_{1}+\alpha_{2} \ln \mathrm{Q}_{\mathrm{it}}+\alpha_{6} \ln \mathrm{Wit}_{1}+\alpha_{7} \ln \mathrm{W}_{\mathrm{it}_{2}}+\alpha_{8} \ln \mathrm{W}_{\mathrm{it}_{3}}+\alpha_{17} \mathrm{~T}}{\mathrm{Q}_{\mathrm{it}}}\right) * \mathrm{TC}
$$

Where:

$\mathrm{TC}$ is the total cost, reflecting the interest expenses and non-interest expenses;

$\mathrm{Q}$ is total asset;

$\mathrm{W}_{1}$ is the cost of deposits, that is the quotient of total interest on total loans;

$\mathrm{W}_{2}$ is the cost of labor, that is the quotient of total wage on total assets;

$\mathrm{W}_{3}$ is the cost of physical capital, that is the quotient of other activities on total fixed assets;

$\mathrm{T}$ is the time trend, reflecting the grasp of technological changes that lead to changes in production capacity over time. We define that $\mathrm{T}=1$ for $2010, \mathrm{~T}=2$ for $2011 \ldots$ and $\mathrm{T}=9$ for 2018 ;

$\alpha_{1} \ldots \alpha_{20}$ are regressors;

$\varepsilon$ is error term.

In agreement with discussions of the previous studies, the study proposes specifications as follows, where the selected variables are expected to determine the factors influencing the competitive capacity in the commercial banks:

\begin{tabular}{|c|c|c|c|c|c|}
\hline No & Variable & Source & Expected sign & Explanation & Calculation \\
\hline \multicolumn{6}{|c|}{ Dependent Variable } \\
\hline 1 & Lerner $_{i t}$ & $\begin{array}{l}\text { Berger et al. (2008) } \\
\text { Fu et al. (2014) }\end{array}$ & & $\begin{array}{l}\text { Degree of } \\
\text { competitive capacity } \\
\text { or market power of a } \\
\text { bank }\end{array}$ & $(\mathrm{P}-\mathrm{MC}) / \mathrm{P}$ \\
\hline \multicolumn{6}{|c|}{ Independent Variables } \\
\hline \multicolumn{6}{|c|}{ Bank-specific Factors } \\
\hline 1 & Lerner $_{i t-1}$ & $\begin{array}{l}\text { Berger et al. (2008) } \\
\text { Fu et al. (2014) }\end{array}$ & + & $\begin{array}{l}\text { Competitive } \\
\text { capacity or market } \\
\text { power in the } \\
\text { previous year }\end{array}$ & $\begin{array}{l}\text { Lerner Index at the } \\
\text { year of }(t-1)\end{array}$ \\
\hline 3 & ETA & Yuanita (2019) & + & Equity-To-Asset & Equity/Assets \\
\hline
\end{tabular}

$$
\begin{aligned}
\text { Lerner }_{\text {it }} & =\Phi_{0}+\Phi_{1} \text { Lerner }_{\text {it- } 1}+\Phi_{2} \mathrm{ETA}_{\mathrm{it}}+\Phi_{3} \mathrm{SIZE}_{\mathrm{it}}+\Phi_{4} \mathrm{LTA}_{\mathrm{it}}+\Phi_{5} \mathrm{LLP}_{\mathrm{it}}+\Phi_{6} \mathrm{HDV}_{\mathrm{it}}+\Phi_{7} \mathrm{HHI}_{\mathrm{it}}+\Phi_{8} \mathrm{GTA}_{\mathrm{it}} \\
& +\Phi_{9} \mathrm{FS}_{\mathrm{it}}+\Phi_{10} \mathrm{FS} 2_{\mathrm{it}}+\Phi_{11} \mathrm{GDP}_{\mathrm{t}}+\Phi_{12} \mathrm{INF}_{\mathrm{t}}+\Phi_{13} \text { Original }_{\mathrm{t}}+\eta_{\mathrm{i}}+\mathrm{e}_{\mathrm{it}}
\end{aligned}
$$

From the literature review and discussion above, we design a research model as in Table 1:

Table 1. Summaries of variables used in the regression model 


\begin{tabular}{|c|c|c|c|c|c|}
\hline & & $\begin{array}{l}\text { Nagore \& Villarroya } \\
(2005)\end{array}$ & & ratio (bank's equity) & \\
\hline 4 & SIZE & $\begin{array}{l}\text { Fernandez \& Garza- } \\
\text { Garcia (2015) } \\
\text { Berger et al. (2008) }\end{array}$ & + & Bank size & Ln (Assets) \\
\hline 5 & LTA & $\begin{array}{l}\text { Maudos \& Solis } \\
(2009) \\
\text { Manlagnit (2011). }\end{array}$ & + & Loans to assets ratio & $\begin{array}{l}\text { Total loans } \\
\text { outstanding as a } \\
\text { percentage of total } \\
\text { assets }\end{array}$ \\
\hline 6 & HDV & $\begin{array}{l}\text { Manlagnit (2011) } \\
\text { Maudos \& Solis } \\
(2009)\end{array}$ & - & $\begin{array}{l}\text { Market share of } \\
\text { mobilized capital }\end{array}$ & $\begin{array}{l}\text { Total mobilized } \\
\text { capital / Total assets }\end{array}$ \\
\hline 7 & LLP & $\begin{array}{l}\text { Schaeck \& Cihák } \\
(2014) \\
\text { Fu et al. (2014) }\end{array}$ & - & Loan loss provisions & $\begin{array}{l}\text { Loan loss provisions } \\
\text { /Gross loan }\end{array}$ \\
\hline 8 & HHI & $\begin{array}{l}\text { Sanya \& Wolfe (2011) } \\
\text { Elsas et al (2010) }\end{array}$ & + & $\begin{array}{l}\text { Revenue } \\
\text { diversification }\end{array}$ & $\begin{array}{l}\text { HHI } \\
(\text { NON/NETOP)2 } \\
(\text { NET/ NETOP)2 } \\
\text { Net interest income } \\
(\text { NET), net } \\
\text { non-interest income } \\
(\text { NON), and net } \\
\text { income (NETOP) = } \\
\text { NET + NON }\end{array}$ \\
\hline 9 & GTA & $\begin{array}{l}\text { Lee et al. (2014) } \\
\text { Sanya \& Wolfe (2011) }\end{array}$ & + & $\begin{array}{l}\text { Growth of total } \\
\text { assets }\end{array}$ & $\begin{array}{l}\text { (total assets this year } \\
- \text { total assets last } \\
\text { year)/ total asset last } \\
\text { year }\end{array}$ \\
\hline 10 & Original & $\begin{array}{l}\text { Mustafa \& Toci (2017) } \\
\text { Tan \& Floros (2013) }\end{array}$ & + & Form of ownership & $\begin{array}{l}\text { Gets } 1 \text { if this is a } \\
\text { government bank, } \\
\text { otherwise gets } 0 \text { if } \\
\text { this is a } \\
\text { non-government bank }\end{array}$ \\
\hline \multicolumn{6}{|c|}{ Competitive Environment Factors } \\
\hline 11 & FS1 & $\begin{array}{l}\text { Manlagnit (2011) } \\
\text { Claessens (2001) }\end{array}$ & + & $\begin{array}{l}\text { The rate of } \\
\text { foreign-owned bank } \\
\text { branches on the } \\
\text { banking sector }\end{array}$ & $\begin{array}{lr}\text { Number } & \text { of } \\
\text { foreign-owned } & \text { bank } \\
\text { branches/Total } & \text { bank } \\
\text { branches } & \end{array}$ \\
\hline 12 & FS2 & $\begin{array}{l}\text { Manlagnit (2011) } \\
\text { Claessens (2001) }\end{array}$ & + & $\begin{array}{l}\text { The rate of } \\
\text { foreign-owned } \\
\text { banks' assets on the } \\
\text { banking sector's } \\
\text { assets }\end{array}$ & $\begin{array}{l}\text { Total assets of } \\
\text { foreign-owned } \\
\text { bank/total assets of } \\
\text { the banking sector }\end{array}$ \\
\hline \multicolumn{6}{|c|}{ Macroeconomic Factors } \\
\hline 13 & GDP & Delis (2012) & + & GDP growth & \\
\hline 14 & INF & Delis (2012) & - & Inflation & \\
\hline
\end{tabular}

Source: Analyzed by the authors 


\subsection{Regression Methods}

In this study, we use pooled ordinary least squares (pooled OLS), fixed effects model (FEM), and random effects model (REM) as in the Figure 1. To select the optimal model by using F-test and Hausman test. The study continues to test multicollinearity by applying variance inflation factors (VIF), Breusch-Pagan test for heteroskedasticity and Wooldridge test for serial correlation. When the model exists diagnostics problems, the study is to perform generalized least square (GLS) in order to correct the diagnostics. Further discussed on the endogeneity in the model, as suggested Yuanita (2019), it could be appeared the correlation between the observation matrix (the regressors) and the error terms. To correct the endogeneity, generalized method of moments (GMM) should be potentially performed (Arellano \& Bond, 1991; Mensi \& Labidi, 2015; Yuanita, 2019).

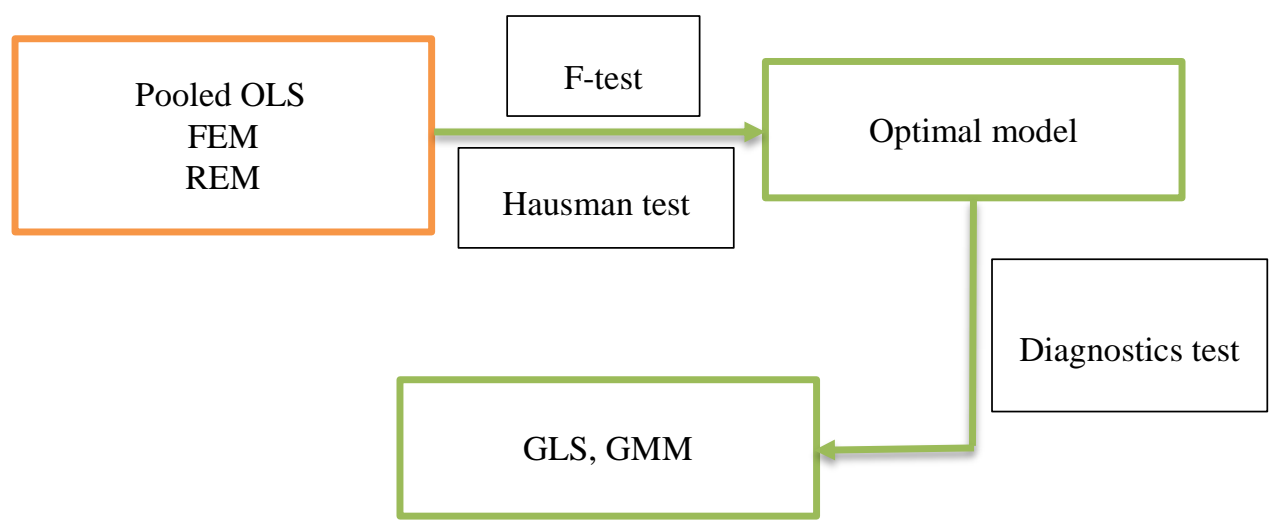

Figure 1. Research analysis

\section{Results}

\subsection{Descriptive Statistics}

Table 2. Descriptive statistics

\begin{tabular}{llllll}
\hline Variable & Obs. & Mean & Std. Dev & Min & Max \\
\hline Dependent Variable & & & & & \\
\hline Lerner & 271 & 0.1794 & 0.0888 & -0.4789 & 0.4366 \\
\hline Independent Variables & & & & & \\
\hline Lerner(-1) & 270 & 0.1790 & 0.0853 & -0.5039 & 0.4354 \\
\hline SIZE & 271 & 18.374 & 1.1685 & 15.922 & 20.995 \\
\hline ETA & 271 & 0.0949 & 0.0429 & 0.0326 & 0.2554 \\
\hline LTA & 271 & 0.5437 & 0.1319 & 0.1473 & 0.8075 \\
\hline HDV & 271 & 0.6362 & 0.1348 & 0.2508 & 0.8937 \\
\hline LLP & 271 & -0.0254 & 0.0724 & -0.6766 & 0.0397 \\
\hline HHI & 271 & 0.0859 & 0.0803 & -0.5633 & 0.2912 \\
\hline GTA & 271 & 1.8372 & 23.843 & -0.9282 & 392.83 \\
\hline FS1 & 271 & 0.2000 & 0.0216 & 0.1837 & 0.2391 \\
\hline FS2 & 271 & 0.1027 & 0.0057 & 0.0954 & 0.1130 \\
\hline GDP & 271 & 0.0624 & 0.0058 & 0.0525 & 0.0708 \\
\hline INF & 271 & 0.0661 & 0.0635 & 0.0019 & 0.2126 \\
\hline
\end{tabular}

Source: Analyzed by the authors 
Table 2 shows the descriptive statistics of the research variables. This research focuses on the sample of 31 commercial banks. It includes state-owned commercial banks and private joint-stock commercial banks in Vietnam. The analysis includes numerous information such as the bank's name, the mean values, the median values, the maximum values, the minimum values, the standard deviation, and the sample sizes of each variable are illustrated. Table 2 indicates that Lerner index (Lerner) has an average value of 0.1794 , but the standard deviation is not too large. This shows the non-significant gap in Lerner index in banks listed on HOSE and HNX in the $2010-2018$ period. Bank's size (SIZE) has an average value of 18.374 with the minimum value of 15.922 and the maximum value of 20.995. The bank's equity (ETA), revenue diversification (HHI), the loans to assets ratio (LTA), and the market share of mobilized capital (HDV) have an average value of $0.0949,0.0859,0.5437$, and 0.6362 respectively, with a major difference. Further, the rate of foreign-owned bank branches on the banking sector (FS1), the rate of foreign-owned banks' assets on the banking sector's assets (FS2) have an average value of 0.2000 , and 0.1027 respectively, with a minor difference. It indicates that a proportion of foreign investment into the banks has slightly changed during this period. In addition, GDP in Vietnam has been stable between 5.25\% and $7.08 \%$ during $2010-$ 2018 period, but inflation has drastically fluctuated between $0.19 \%$ and $21.26 \%$.

Table 3. Correlation matrix

\begin{tabular}{|c|c|c|c|c|c|c|c|c|c|c|c|c|c|}
\hline & Lerner & Lern. 1 & SIZE & ETA & $L T A$ & $H D V$ & $L L P$ & $H H I$ & GTA & FS1 & $F S 2$ & $G D P$ & $I N F$ \\
\hline Lerner & 1 & & & & & & & & & & & & \\
\hline $\operatorname{Lern}(-1)$ & 0.648 & 1 & & & & & & & & & & & \\
\hline SIZE & -0.024 & -0.060 & 1 & & & & & & & & & & \\
\hline ETA & 0.390 & 0.361 & -0.725 & 1 & & & & & & & & & \\
\hline LTA & 0.157 & 0.069 & -0.095 & 0.322 & 1 & & & & & & & & \\
\hline $\mathrm{HDV}$ & 0.261 & 0.215 & 0.141 & -0.026 & 0.02 & 1 & & & & & & & \\
\hline LLP & -0.247 & -0.073 & -0.312 & 0.404 & 0.624 & -0.196 & 1 & & & & & & \\
\hline $\mathrm{HII}$ & -0.452 & -0.030 & 0.100 & -0.254 & -0.162 & -0.008 & -0.223 & 1 & & & & & \\
\hline GTA & 0.082 & 0.106 & 0.003 & 0.025 & -0.051 & 0.031 & -0.104 & 0.003 & 1 & & & & \\
\hline FS1 & 0.061 & -0.089 & -0.235 & 0.224 & 0.277 & -0.021 & 0.193 & -0.168 & -0.041 & 1 & & & \\
\hline FS2 & 0.060 & 0.054 & 0.180 & -0.180 & -0.270 & 0.045 & -0.194 & 0.025 & -0.031 & -0.52 & 1 & & \\
\hline GDP & 0.079 & -0.040 & -0.265 & 0.189 & 0.241 & -0.041 & 0.128 & -0.145 & -0.112 & 0.635 & -0.46 & 1 & \\
\hline INF & 0.166 & 0.296 & 0.255 & -0.227 & -0.296 & 0.307 & -0.594 & 0.196 & 0.046 & -0.27 & 0.147 & -0.25 & 1 \\
\hline
\end{tabular}

Source: Analyzed by the authors

Table 3 indicates the correlation matrix for our key variables. As a result, the highest correlation (-0.594) observed is between LLP and INF. Nguyen and Do (2020) argued that multicollinearity existence can be found if correlation coefficient is 0.8 and more. It is accordingly confirmed that there is no absence of multicollinearity in our regression analyses.

\subsection{Regression Results}

Based on the analysis of Lerner index for the commercial banks in Vietnam in the period of 2010 - 2018, Figure 2 indicates that the index ranges between $14 \%$ and $24 \%$. This index has increasingly changed in a downtrend over time so that the market power of a bank has been decreased. Not only that, Lerner index has also improved at a steep trend since 2015. At the period of 2018-2019, GDP in the country has also enhanced at the highest growth since 2008 with the rate of 7.08 percent in 2018 and 7.02 percent in 2019. However, this effect has not certainly improved the competitive capacity of the banking system. Therefore, it is consistent that a lower value of Lerner index, a bank is less likely to be able to charge over its marginal cost, hence the less greater its monopoly power in the market. 
Deeply discussed on the commercial banks, Figure 3 shows that a private joint-stock commercial bank is more likely to charge over its marginal cost than a state-owned commercial bank due to the higher level of Lerner index in the private bank. Further, there exists a lower the price elasticity of demand of a private bank's product that any increase in the price of the product will be hard to switch to substitute goods and substitute banks for customers. This can increase the ability of monopolist to trade its products at a higher markup. In contrast, the effects of a state bank could steadily improve because of increase of Lerner index since 2015.

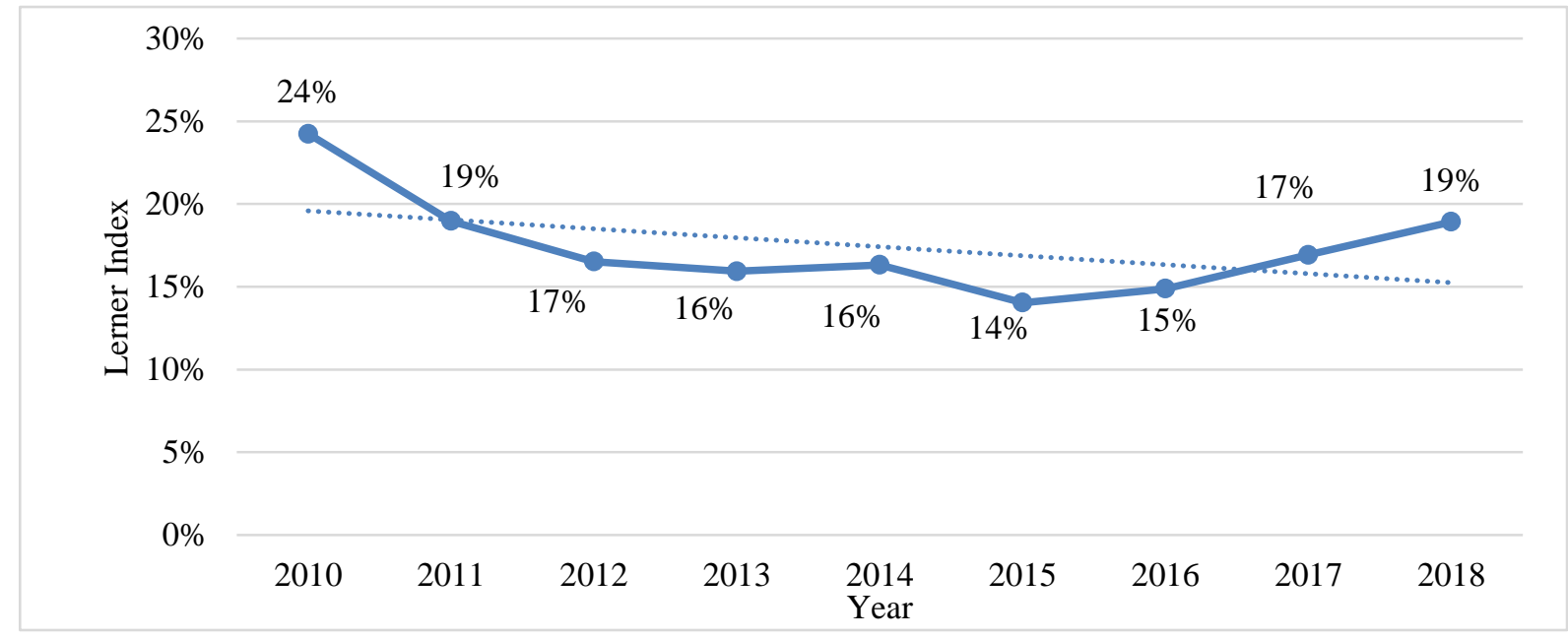

Figure 2. Average Lerner index of commercial banks in the period of 2010-2018

Source: Analyzed by the authors

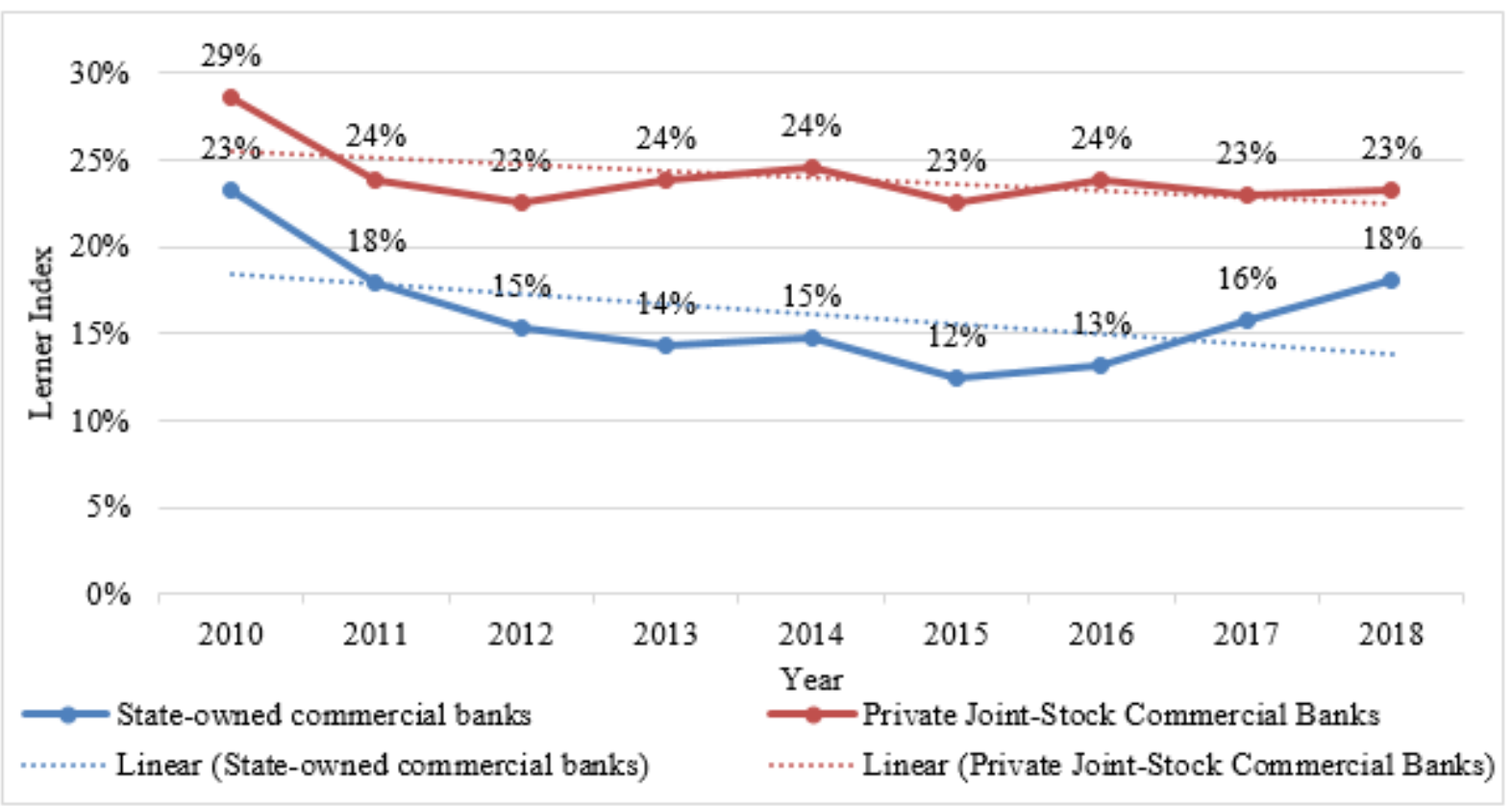

Figure 3. Lerner Index of Vietnamese banks in the period of 2010-2018

Source: Analyzed by the authors

Based on the approach of Lerner (1934), Kasman \& Carvallo (2014). Factors influencing the competitive capacity are identified and divided into 3 groups: Bank-specific factors, Competitive Environment Factors, and 
Macroeconomic Factors. The pooled OLS, FEM and REM have been performed to calculate in the panel data. To correct diagnostics problems, GLS and GMM are more preferred.

Table 4. Regression results

\begin{tabular}{|c|c|c|c|c|c|}
\hline Variable & OLS & FEM & REM & GLS & GMM \\
\hline Lerner(-1) & $0.4892 * * *$ & $0.2303 * * *$ & $0.4892 * * *$ & $0.4892 * * *$ & $0.2291 * * *$ \\
\hline ETA & $0.5882 * * *$ & $0.7082 * * *$ & $0.5882 * * *$ & $0.5882 * * *$ & $0.5824 * * *$ \\
\hline SIZE & $0.0296^{* * *}$ & $0.0564 * * *$ & $0.0296 * * *$ & $0.0296 * * *$ & $0.0385 * * *$ \\
\hline LTA & 0.0456 & 0.0578 & 0.0456 & 0.0456 & $0.2469 * *$ \\
\hline LLP & $-0.1135^{* *}$ & -0.0694 & $-0.1135 * *$ & $-0.1135 * *$ & $-0.1455 * * *$ \\
\hline HDV & -0.0252 & $-0.1476^{* * *}$ & -0.0252 & -0.0252 & $-0.1468 * *$ \\
\hline HHI & $-0.1242 * * *$ & $-0.1418 * * *$ & $-0.1242 * * *$ & $-0.1242 * * *$ & $-0.1290 * * *$ \\
\hline GTA & 0.00009 & 0.00012 & 0.00009 & 0.00009 & $0.00009 * * *$ \\
\hline FS1 & 0.1528 & -0.0274 & 0.1528 & 0.1528 & $0.1922 *$ \\
\hline FS2 & $1.8311 * * *$ & $2.0381 * * *$ & $1.8311 * * *$ & $1.8311249 * * *$ & $1.9301 * * *$ \\
\hline GDP & $1.4103^{*}$ & $1.3059 *$ & $1.4103^{*}$ & $1.4103^{*}$ & $-1.2536^{*}$ \\
\hline INF & $0.1536^{* *}$ & $0.1959 * *$ & $0.1536^{* *}$ & $0.1536^{* *}$ & $0.1382 * *$ \\
\hline Original & $0.0263 * *$ & $0.0583^{* *}$ & $0.0263^{* *}$ & $0.0263 * *$ & $0.0487 * *$ \\
\hline _cons & $-0.7379 * * *$ & $-1.0991 * * *$ & $-0.7379 * * *$ & $-0.7379 * * *$ & $-0.7264 * * *$ \\
\hline No of Obs. & \multicolumn{5}{|l|}{271} \\
\hline No of groups & \multicolumn{5}{|l|}{31} \\
\hline Instrument variable & \multicolumn{5}{|l|}{26} \\
\hline Mean VIF & \multicolumn{5}{|l|}{1.94} \\
\hline F-test & \multicolumn{5}{|c|}{$\mathrm{F}$ test that all $\mathrm{u}_{-} \mathrm{i}=0: \mathrm{F}(30,228)=3.02 ;$ Prob $>\mathrm{F}=0.0000$} \\
\hline Hausman test & \multicolumn{5}{|c|}{$\begin{array}{l}\text { Test: Ho: difference in coefficients not systematic } \\
\text { chi2(12) }=(b-B)^{\prime}\left[\left(V_{-} b-V_{-} B\right)^{\wedge}(-1)\right](b-B)=878.20 \\
\text { Prob>chi2 }=0.0000 \\
\left(V_{-} b-V \_B \text { is not positive definite }\right)\end{array}$} \\
\hline Breusch- Pagan test & $\begin{array}{l}\text { Test: } \operatorname{Var}(\mathrm{u} \\
\text { chibar2(01) } \\
\text { Prob > chib }\end{array}$ & 1.0000 & & & \\
\hline Wooldridge test & $\begin{array}{l}\text { Wooldridge } \\
\text { H0: no first } \\
\mathrm{F}(1,30)=4 \\
\text { Prob }>\mathrm{F}=\end{array}$ & $\begin{array}{l}\text { or autocorrela } \\
\text { autocorrelatic }\end{array}$ & $\mathrm{n}$ in panel data & & \\
\hline $\operatorname{AR}(2)$ & \multicolumn{5}{|c|}{$\operatorname{Pr}>z=0.314$} \\
\hline Sargan test & \multicolumn{5}{|c|}{ Prob $>$ chi $2=0.523$} \\
\hline Hansen test & \multicolumn{5}{|c|}{ Prob $>$ chi $2=0.524$} \\
\hline
\end{tabular}

Note: $(* * *),(* *),(*)$ denote for the significant level of $1 \%, 5 \%$, and $10 \%$, respectively

Source: Analyzed by the authors 
Table 4 shows the regression results of the model on the relationship between factors impacting on the competitive capacity in the commercial banks in Vietnam. To select the best model, multicollinearity was measured by variance inflation factors (VIF), the multicollinearity value is 1.94 and less than 10 so that the multicollinearity is not found. To select the best model between FEM and pooled OLS, F-test with Prob $>\mathrm{F}=0.0000$, meaning that FEM is more appropriate. Furthermore, Hausman test also indicates that FEM is better than REM due to Prob $>$ chi2 $=0.000$.

Breusch-Pagan test for heteroskedasticity and Wooldridge test serial correlation show that Prob > chi $2=0.0000$ and Prob $>F=0.0000$. It is noted that there exist heteroskedasticity and autocorrelation in the model. To be precise, the study will apply generalized least square (GLS) in order to correct the diagnostics. Further, through Hansen test with Prob $>$ chi $2=0.524$ and more than 0.1 as well as the test of AR (2) with $\operatorname{Pr}>\mathrm{z}=0.314$ and more than 0.1 , it concludes that the model is more suitable and no autocorrelation in the model.

\section{Discussion}

According to the literature review, the factors influencing competitive capacity of commercial banks have been clarified and have reflected in the case of Vietnam. As for statistical investigation, the results of the analysis describe that it was significant in some main hypotheses except as follows:

\subsection{Bank-Specific Factors}

- $\quad$ Lerner Index in the previous year (Lerner_1)

The result shows that the coefficient of Lerner1 is positive and significant. It is better to say that the impact of the Lerner index in the previous year on the competitive capacity is actually positive. It means that a bank with a greater of competitive capacity in the previous year will significantly generate competitive capacity in the current year. This finding is associated with Delis (2012) in the study based on bank-level data for 84 banks worldwide.

\section{- $\quad$ Equity-To-Asset ratio (ETA)}

In this study, the equity to asset ratio was considered in the context of competitive capacity. The results show that ETA has a positive influence on the probability of competitive capacity, like the finding of Delis (2012). It is also not consistent with the theoretical arguments that a bank with a higher level of ETA is consistent with a higher level of Lerner index and also in relation to more competitive capacity in that bank. Therefore, the level of competition of that bank in the market has decreased. As results related to theoretical studies, a negative effect could be found in the studies of Berger et al. (2008) analyzing data for 8,235 banks in 23 developed countries, Soedarmono (2011) in Asian banks.

\section{- $\quad$ Bank Size (SIZE)}

In respect to Bank Size, the coefficient is positive and significant. Indicating that the bank size has positively significant relationship with the competitive capacity of the bank. It reveals that an increase in bank size will accelerate the competitive capacity of the bank. It is correlated with the findings of Soedarmono et al. (2011), Kasman \& Carvallo (2014). It is therefore noted that a bank needs to enhance the scope of doing business in order to improve its assets that affect the competitive capacity.

\section{- Loans to assets ratio (LTA)}

The results show that LTA has a positive and significant influence on the probability of competitive capacity of a bank. In fact, the income of Vietnam's commercial banks has been mostly contributed by loans. If an increase in LTA can importantly generate Lerner index and then decline the competition the banks with the market. In addition, the results obtained in the study were found to be consistent with previous studies in the literature of Maudos \& Solis (2009) and Manlagnit (2011). More specifically, an increase in LAT could be explained for such high result and reducing high transaction costs in banks, so it could enhance its profit.

\section{- Market share of mobilized capital (HDV)}

The result implies that HDV is statistically significant at 5\% level of significance and negatively correlated with competitive capacity of a bank. This result is same from some previous arguments that when HDV increases, a bank has to look for additional cost for mobilized capital and the cost of mobilized capital could be increased. It also requests for a bank that needs to balance risk and return. Certainly, investment in high risk must request the prospect of a high return in order to attract capital in the capital structure (Modigliani \& Miller, 1963).

\section{- $\quad$ Loan loss provisions (LLP)}

The study found evidences of negative impact from LLP on competitive capacity of a bank at $1 \%$ level of significance. This conclusion is consistent with Fu et al. (2014) discussed a negative linkage between these two 
variables. This is justified by the fact that the banking sector in Vietnam during the period of $2010-2012$ faced some problems in operation such as the decline of lending assets and increase of bad debts affect the performance as well as reduce the competitiveness of banks.

\section{- $\quad$ Revenue diversification (HHI)}

The result denotes that $\mathrm{HHI}$ is statistically significant at $1 \%$ level of significance and negatively correlated with competitive capacity of a bank. The bank possessing a large diversification of revenue that reflected by numerous sources of revenue in the business will decrease the pressure of competition in that bank or competitive capacity of a specific bank related to the market will increase. This observation is similar to Carbó et al. (2009) assessing the competitive position of banking sector in 14 European nations. For the case of Vietnam, this evidence can be explained by the expansion of business types and services of Vietnamese commercial banks in the recent period but the internal strength has not been effective enough to promote the effectiveness of competition with foreign counterparts. In addition, effects of revenue diversification of Vietnamese commercial banks has not been significantly effective, i.e. the quality of card payment services, convenient payment methods, use of FINTECH has not created on customer satisfaction like foreign banks.

\section{- $\quad$ Growth of total assets (GTA)}

The regression results show that GTA has a positive impact on competitive capacity of banks listed Ho Chi Minh City Stock Exchange and Hanoi Stock Exchange. Importantly, increasing total assets has been known as a factor to strengthen the internal strength of the bank and to increase its position in the harsh business environment. This argument is easy to explain in micro-economics, a larger firm is often more efficient due to the economies of scale. Therefore, a large bank has a lower cost in information processing and information collection (Boyd \& Runkle, 1993) or easy to diversify income through expanding business products and services (Smirlock, 1985)

\section{- Form of Ownership (Original)}

Form of ownership and competitive capacity are positively correlated in this study. It indicates that state-owned commercial banks have a higher level of competitive capacity than its counterparts. This result is similar to Tan \& Floros (2013) using a panel data in China's commercial banks. For Vietnam, state-owned commercial banks have many preferences such as high equity, high proportion of total bank assets compared to total assets of the whole credit institution systems, cheap cost of capital.

\subsection{Competitive Environment Factors}

At the significance level of $10 \%$, the explanatory variable of FS1 is statistically significant and has a positive effect on competitive capacity with a coefficient of $\beta_{\mathrm{FS} 1}=0.1922$. This shows that an increase in number of foreign bank branches could significantly promote the Lerner index in agreement with an increase in the level of competition among banks. This is justified by the fact that the increase in the amount of foreign bank branches in the host country will create more opportunities to acquire modern technology and business management experience of developed countries.

Using the explanatory variable of FS2, it has a positive impact on competitive capacity at $1 \%$ significance level. It is important to point out that a larger proportion of foreign banks in terms of its total assets in the banking sector could spill over its comparative advantage, productivity and international technology spillovers on local banks. In some situations, foreign investment is found to be more productive than domestic investment (Jarvocik, 2004). As suggested in Claessens et al. (2001) assessing over 7900 observations in the bank sector from 80 countries in the period of 1988-1995, Manlagnit (2011) in the Philippines, foreign banks will create competitive pressure for domestic banks. This finding is also in line with the studies of Denizer (2000) in Turkey's financial market in the flow of the large number of foreign banks entering the Turkish banking sector and supporting for the banking sector in the host country.

\subsection{Macroeconomic Factors}

There are two macroeconomic factors used in this study. Firstly, GDP growth has negatively and insignificantly affected competitive capacity. Secondly, inflation has positively impacted on competitive capacity at a significant level of 5\%. This is explained by the fact that when GDP increases, it will not create more opportunities for banks, therefore promote competition but few banks could not grasp these benefits. In the report of State Bank of Vietnam, although banking sector has been likely to play a key role in leading the economic growth in recent years, but there could certainly be major changes in positions in last decade, especially the changes in banks' profit ranking due to a fierce competition in making profit among banks (Nguyen, 2020). Some banks have faced the non-performing loans 
(NPL) and lost profit. In contrast to inflation that can raise the cost of capital for domestic banks, and creates advantages for foreign banks that can manage a competitive cost of capital. As shown in the previous studies, Tan \& Floros (2013) also indicated that cost efficiency is positively consistent with bank profitability in the case of China's banking industry.

\section{Conclusions and Implications}

This article uses an unbalanced panel data to examine the factors influencing of competitive capacity of commercial banks in Vietnamese banks for the period 2010 -2018. The secondary data is collected from in Ho Chi Minh City Stock Exchange (HOSE) and Hanoi Stock Exchange (HNX) and included both state-owned commercial banks and private joint-stock commercial banks.

The study obtains three major conclusions. First, the factors influencing on competitive capacity of commercial banks have predominantly influenced by two bank-specific characteristics, competitive environment and macroeconomic factors. More specifically, factors such as the equity-to-asset ratio, bank size, the loans to assets ratio, the growth of total assets and form of ownership are positively associated with competitive capacity of a bank. Further, a bank with a higher level of competitive capacity in the previous year will outstandingly promote competitive capacity in the current year. In addition, we report that loan loss provisions, the market share of mobilized capital, and ability of income diversification have negatively impacted on competitive capacity of a bank.

A possible finding deals with the positive influence of foreign investment in the banking sector on competitive capacity. Obviously, we argue that a larger number of foreign bank branches in the host country could further encourage competitive capacity in the banking system. Similarly, a larger proportion of foreign banks in terms of its total assets in the banking system could generally increase competitive capacity in a bank. Finally, economic performance has insignificantly affected competitive capacity while a positive effect from inflation on competitive capacity could be found at a significant level of $5 \%$.

This study has important implications for future researchers. Firstly, the study has mostly focused on bank-specific factors and its influence on the market power in the banking system, it is further noted that the study should concentrate other factors, in particular in macroeconomic factors and the competition from foreign investment in the banking system. Secondly, the factors as political stability, geographical location, or government policies should also be analyzed. Further discussed on the methodology, the study needs to test stationary (panel unit root), it is theoretical to confirm that unit root is a stochastic trend in a time series. The method is helpful to explore integration between time-series data.

\section{References}

Arellano, M., \& Bond, S. (1991). Some tests of specification for panel data: Monte Carlo Evidence and an application to employment equations. Review of Economic Studies, 58(2), 277-297. https://doi.org/10.2307/2297968

Berger, A. N., Klapper, L. F., \& Turk-Ariss, R. (2008). Bank competition and financial stability. Journal of Financial Services Research, 35, 99-118. https://doi.org/10.1007/s10693-008-0050-7

Boyd, J. H., \& Runkle, D. E. (1993). Size and performance of banking firms: Testing the predictions of theory. Journal of Monetary Economics, 31(1), 47-67. https://doi.org/10.1016/0304-3932(93)90016-9

Carbó, S., Humphrey, D., Maudos, J., \& Molyneux, P. (2009). Cross-Country comparisons of competition and pricing power in European banking. Journal of International of Money and Finance, 28(1), 115-134. https://doi.org/10.1016/j.jimonfin.2008.06.005

Casu, B., \& Girardone, C. (2006). Bank Competition, Concentration and Efficiency in the Single European Market. The Manchester School, 74(4), 441-468. http://dx.doi.org/10.1111/ j.1467-9957.2006.00503.x

Chen, X., Yao, L., Xu, Z., \& Xu, Q. (2018). Foreign entry and bank competition on financial products in China: A model of bank size. Pacific-Basin Finance Journal, 49, 43-59. https://doi.org/10.1016/j.pacfin.2018.03.005

Claessens, S., Demirgüç-Kunt, A., \& Huizinga, H. (2001). How does foreign entry affect domestic banking markets? Journal of Banking and Finance, 25(5), 99-118. https://doi.org/10.1016/S0378-4266(00)00102-3

Delis, M. D. (2012). Bank competition, financial reform, and institutions: The importance of being developed. Journal of Development Economics, 97(2), 450-465. https://doi.org/10.1016/j.jdeveco.2011.05.012

Denizer, C. (2000). Foreign entry in Turkey's banking sector, 1980-97. World Bank Policy Research Working Paper No.2462. Retrieved from https://ssrn.com/abstract $=632532$ 
Elsas, R., Hackethal, A., \& Holzhäuser, M. (2010). The anatomy of bank diversification. Journal of Banking \& Finance, 34(6), 1274-1287. https://doi.org/10.1016/j.jbankfin.2009.11.024

Fernandez, R. O., \& Garza Garcia, J. (2015). The relationship between bank competition and financial stability: A case study of the Mexican banking industry. Ensayos Revista de Economía, XXXIV(1), 103-120.

Fu, X., Lin, Y., \& Molyneux, P. (2014). Bank competition and financial stability in Asia Pacific. Journal of Banking and Finacce, 38, 64-77. https://doi.org/10.1016/j.jbankfin.2013.09.012

Hussain, S., Hassan, A.A.G. (2020). The Reflection of Exchange Rate Exposure and Working Capital Management on Manufacturing Firms of Pakistan. Talent Development and Excellence, 12 (2s), 684-698. http://iratde.com/index.php/jtde/article/view/232

Hussain, S., Hassan, A.A.G., Bakhsh, A., Abdullah, M. (2020). The impact of cash holding, and exchange rate volatility on the firm's financial performance of all manufacturing sector in Pakistan. International Journal of Psychosocial Rehabilitation, 24 (7), 248-261. DOI: 10.37200/IJPR/V24I7/PR270025

Javorcik, B. S. (2004). Does foreign direct investment increase the productivity of domestic firms? In search of spillovers through backward linkages. The America Economic Review, 94(3), 605-627. https://doi.org/10.1257/0002828041464605

Kamran, H.W., Haseeb, M., Nguyen, V.C., Nguyen, T.T. (2020). Climate change and bank stability: The moderating role of green financing and renewable energy consumption in ASEAN. Talent Development and Excellence, 12(2s), 3738-3751. Retrieved from http://iratde.com/index.php/jtde/article/view/1280/979

Kasman, A., \& Carvallo, O. (2014). Financial stability, competition and efficiency in Latin American and Caribbean banking. Journal of Applied Economics, 17, 301-324. https://doi.org/10.1016/S1514-0326(14)60014-3

Lee, C. C., Hsieh, M. F., \& Yang, S. J. (2014). The relationship between revenue diversification and bank performance: Do financial structures and financial reforms matter? Japan and the World Economy, 39, 18-35. https://doi.org/10.1016/j.japwor.2013.11.002

Lerner, A. P. (1934). The concept of monopoly and the measurement of monopoly power. The Review of Economic Studies, 1(3), 157-175. https://doi.org/10.2307/2967480

Manlagnit, M. C. V. (2011). Cost efficiency, determinants, and risk preferences in banking: A case of stochastic frontier analysis in the Philippines. Journal of Asian Economics, 22(1), 23-35. https://doi.org/10.1016/j.asieco.2010.10.001

Maudos, J., \& Solis, L. (2009). The determinants of net interest income in the Mexican banking system: An integrated model. Journal of Banking and Finance, 33(10), 1920-1931. https://doi.org/10.1016/j.jbankfin.2009.04.012

Mensi, S., \& Labidi, W. (2015). The effect of diversification of banking products on the relationship between market power and financial stability. American Journal of Economics and Business Administration, 7(4), 185-193. https://doi.org/10.3844/ajebasp.2015.185.193

Modigliani, F., \& Miller, M., (1963). Corporate income taxes and the cost of capital: A correction. The American Economic Review, 53(3), 433-443. Retrieved from https://www.jstor.org/stable/1809167

Mukherjee, S., Bhattacharjee, S., Sharma, S., Paul, A. (2020). People's Perception about Quarantine and its Impact on Occupational Stress: Community-Based Online Survey Following Covid-19 Outbreak in India. International Journal of Disaster Recovery and Business Continuity, 11(1), 1486 - 1496. http://sersc.org/journals/index.php/IJDRBC/article/view/19469/9904

Mukherjee, S., Bhattacharjee, S., Paul, A., Banerjee, U. (2020). Assessing Green Human Resource Management Practices in Higher Educational Institute. Test Engineering and Management, 82, 221 - 240. http://www.testmagzine.biz/index.php/testmagzine/article/view/972/879

Mustafa, A., \& Toci, V. (2017). Estimation of the banking sector competition in the CEE countries: The Panzar-Rosse approach. Zbornik Radova Ekonomskog Fakultet au Rijeci, 35(2), 459-485. https://doi.org/10.18045/zbefri.2017.2.459

Nagore, A., \& Villarroya, J.M. (2005). Explaining market power differences in banking: A cross-country study. Working Papers, Serie EC 2005-10. Instituto Valenciano de Investigaciones Económicas, S.A. (Ivie).

Nguyen, V.C. (2020). Human capital, capital structure choice and firm profitability in developing countries: An 
empirical study in Vietnam. Accounting, 6(2), 127-136. https://doi.org/10.5267/j.ac.2019.11.003

Nguyen, V. C. (2020). Trade Liberalization, Economic Reforms and Foreign Direct Investment - A Critical Analysis of the Political Transformation in Vietnam. International Journal of Advanced Science and Technology. International Journal of Advanced Science and Technology, 29(3), 6837 - 6850. Retrieved from http://sersc.org/journals/index.php/IJAST/article/view/7336

Nguyen, V.C., \& Do, T. T. (2020). Impact of exchange rate shocks, inward FDI and import on export performance: a cointegration analysis. Journal of Asian Finance, Economics and Business, 7(4), 163-171. https://doi.org/10.13106/jafeb.2020.vol7.no4.163

Sanya, S., \& Wolfe, S. (2011). Can banks in emerging eEconomies benefit from revenue diversification? Journal of Financial Services Research, 40, 79-101. https://doi.org/10.1007/s10693-010-0098-z

Schaeck, K., \& Cihák, M. (2014). Competition, efficiency, and stability in banking. Financial Management, 43(1), 215-241. Retrieved from https://www.jstor.org/stable/43280177

Smirlock, M. (1985). Evidence on the relationship between concentration and profitability in banking. Journal of Money, Credit and Banking, 17(1), 69-83. https://doi.org/10.2307/1992507

Soedarmono, W., Machrouh, F., \& Tarazi, A. (2011). Bank market power, economic growth and financial stability: Evidence from Asian banks. Journal of Asian Economics, 22(6), 460-470. https://doi.org/10.1016/j.asieco.2011.08.003

Tan, Y. A., \& Floros, C. (2013). Risk, capital and efficiency in Chinese banking. Journal of International Financial Markets Institutions and Money, 26, 378-393. https://doi.org/10.1016/j.intfin.2013.07.009

Tran, V. D., \& Van, N. (2013). Enhancing of the quality of public policy promulgation in Vietnam. Journal of State and Law, 371, 28-35. Retrieved from http://www.vjol.info/index.php/ssir/article/viewArticle/16224

Van, N. (2019). Improving quality of FDI attraction into Vietnam for the coming period - From the institutional view. Review of Finance, 704, 18-21. Retrieved from 10.31219/osf.io/k5eqb

Yuanita, N. (2019). Competition and bank profitability. Economic Structures, 8(31). https://doi.org/10.1186/s40008-019-0164-0

Zouaoui, H., \& Zoghlami, F. (2020). On the income diversification and bank market power nexus in the MENA countries: Evidence from a GMM panel-VAR approach. Research in International Business and Finance, 52, 101186. https://doi.org/10.1016/j.ribaf.2020.101186 